\title{
OVERPARENTING IN EDUCATION REALITY: TEACHER EXPERIENCE
}

\author{
Lijana Navickienė ${ }^{1}$, Ilona Kupčikienè ${ }^{1}$, Eglẻ Stasiūnaitiené ${ }^{2}$ Mehmet Tokgöz ${ }^{3}$ Emrah Koçak ${ }^{3}$ \\ ${ }^{1}$ Kaunas University of Applied Sciences, Lithuania, \\ ${ }^{2}$ Vytautas Magnus University, Lithuania. \\ ${ }^{3}$ Konya Provincial Directorate of National Education, Turkey
}

Keywords: parenting style, overparenting, teacher experience.

\footnotetext{
Summary

Most parents would agree that parenting is extremely complex and challenging. It is the process of promoting and supporting the physical, emotional, social and intellectual development of a child from infancy throughout a person's life. Children are not born successful or unsuccessful. It is up to the parents and their behaviours to become what they become later. Normative or healthy parenting is a precondition for a child's success, selfconfidence, and autonomy. Meanwhile, non-normative, unhealthy parenting or overparenting may have a harmful impact on a child's social skills and overall life.

The research was aimed to gather teachers' experiences about the existing parenting behaviours and to reveal the dominant parenting patterns that may be observed in nowadays child-raising practices. For this aim the research instrument was constructed designing of which was based on a specific focus on different areas of unhealthy, non-normative parenting. An international study was conducted that led to identification of the key aspects of the experience of teachers working with the overprotective parents and their children. 262 teachers from Portugal, Slovenia, Turkey, Romania and Lithuania participated in the survey.

The study findings served to reveal the dominant behaviours of overparenting observed by the teachers The findings also allowed to define the difficulties that teachers face in dealing with overparenting parents and overparented children.

The study was conducted in the framework of the international project "Overparenting - allow your children to make mistakes", project No. 2020-1-PT01KA204-078497.
}

\section{Introduction}

Raising children in a family is a complex and often problematic social-pedagogical process. Its effectiveness depends on the family microclimate, communication style, personal example, and other aspects. The overall approach and attitudes that parents have about their children and take to guiding, controlling, and socializing them create an emotional climate that is referred to as "parenting style" [1]. It may be defined as a unique pattern of parental behaviour characterized by level of support, control and autonomy granting demonstrated by parents [2].

Research on parenting styles is complicated by a number of factors. One primary challenge is that it is difficult to distinguish among the different parenting styles since parents can exhibit elements of each parenting dimension. Researchers have supported the notion that parents typically cannot be characterized into a single parenting style [3]. Therefore it is more reasonable to discuss parenting patterns by singling out normative and non-normative parenting [2]. According to the authors normative parenting refers to positive or effective parenting which are distinguished by three dimensions: warmth and support shown to a child to facilitate an emotional connection (e.g., acceptance, affection, involvement, nurturance), behavioural control of the child to foster mature behaviour (e.g., limit setting, supervision, reasoning about consequences), autonomy granting (e.g., independence, self-governance) to promote emotional and psychological self-reliance.

Non-normative parenting refers to unhealthy, overparenting behaviours, evidence of which may be seen across the parenting styles distinguished by Baumrind [4] and Maccoby and Martin [5]. Overparenting is theorized to involve high levels of parental support, behavioural control, anxiety, and low levels of autonomy granting. Overparenting involves the application of developmentally inappropriate levels of parental directiveness, tangible assistance, problem-solving, 
monitoring, and involvement into the lives of children. Based on theories of family enmeshment, effective parenting, and personality development, this parenting behaviour was hypothesized to be associated with negative traits in parents (i.e., anxiety and regret) as well as in young adult children (i.e., narcissism, poor coping styles, anxiety, and stress) [2]. The paradox of this form of parenting is that, despite seemingly good intentions, the preliminary evidence indicates that it is not associated with adaptive outcomes for young adults and may indeed be linked with traits that could hinder the child's success.

Non-normative, yet effortful parenting has been described using a variety of terms, including: helicopter parenting [6 cited in 2], intrusive parenting [2], overprotective parenting $[2,7]$, oversolicitous parenting, lawnmower parenting [6 cited in 2], overly effortful parenting [8], and overparenting $[2,8]$. Although similar, these terms are often used in conceptually different ways and researchers have noted that the meanings of these non-normative parenting approaches can be confusing.

The helicopter parent (sometimes labelled as overprotective or over-solicitous) is defined as a parent who excessively shields and problem-solves for his/her child rather than allow the child to experience failure or challenge. In this way, the helicopter parent prevents his/her child from demonstrating personal growth [6,9]. Padilla-Walker and Nelson [10] conceptualized the helicopter parent as one that is "high on warmth/support, high on control, and low on granting autonomy". The intrusive parent (sometimes called an overly effortful parent) over-schedules and micromanages their children, discouraging free time and independent behaviour. Intrusive parents often function poorly without their child $[7,10]$. Overprotective parents are hypersensitive, and they often overreact to anything related to their children. They are overly cautious over activities their child engages in. They remind their child about safety and danger constantly. They complain about their child's bad grade and fight with the school to change it. Oversolicitous parent haves or shows too much solicitude or concern for someone's health, happiness, comfort, etc. excessively solicitous (overprotective has the same meaning). The lawnmower parent quite literally "mows" problems out of their child's path [8]. They seek to remove all perceived obstacles from their child's growth and are frequently cited as interfering with academics and athletics to excess. Overparenting is the term that best represents non-normative, yet effortful (as opposed to permissive) parenting styles. Segrin, et al. [9], offering what may be the most cogent definition of an overparenting, suggested that "individuals who enact this form of parenting appear hyper-involved in their children's lives, risk averse, and preoccupied with their children's emotional well-being" (p. 570-571).

Research suggests that parenting styles have major implications for a child. Parenting styles are associated with child's mental health, physical health, and socioemotional development $[12,13]$. Parenting styles have been found to have significant impact on child's well-being in the domains of social competence, academic performance, psychosocial development, and problem behaviour $[2,14]$. Certain parenting behaviours can serve to support, facilitate and enhance child's healthy outcomes or, conversely, diminish his or her biological predispositions and have an adverse effect on the child's development.

It is reasonable to assume that many instances of overparenting are enacted with intentions to ensure and enhance the child's success in life. However, the available research on this parenting practice points to more negative than positive outcomes for the child. For instance, in young children overparenting has been linked to anxious, withdrawn, depressive, and insecure tendencies $[15,16]$. Further, the parenting style characterized as helicopter parenting is positively correlated with dependent personality traits and neuroticism in young adults $[17,18]$ and lower levels of a variety of indicators of psychological well-being [19]. Overinvolved parenting has also been shown to be associated with lower self-efficacy [20] and higher entitlement [6] in young adults.

The article is aimed at presenting teachers' experiences about the parenting behaviours that may be observed in current parenting practices and faced by teachers in their daily professional activity. Also teachers' perception about the consequences of parenting technics on children's behaviours and attitudes towards school life are discussed and difficulties faced by teachers when dealing with parents and overparented children are revealed.

\section{Research methodology}

The research was carried out in January-February, 2021. Data for the study was obtained from a comprehensive online survey of teachers (N=262) across Portugal, Slovenia, Lithuania, Turkey and Romania. Convenient sampling technique was used. The questionnaire was created through Google forms and the link using social media and personal contacts (emails, FB) was sent to kindergartens, schools and teachers in person in the mentioned countries.

The survey was conducted in accordance with the basic ethical principles. The research instrument included the introductory part in which the scope and objectives of the survey were defined as well as future follow-up were explained. The survey was voluntary and confidential. These principles helped to ensure the reliability and objectivity of the collected 
data. The development of survey instrument was based on the identified beliefs, attitudes and behaviours in literature on overparenting. The survey questionnaire was composed of closed-ended (quantitative) and openended (qualitative) questions. Closed-ended questions included two main types of questions:

the single-answer multiple choice questions aimed to reveal socio-demographic characteristics of respondents-teachers: gender, work/teaching area, work experience, number of children teachers are working with.

the series of Likert scale items with the same response options (strongly disagree, disagree, neutral, agree, strongly agree) that allowed to specify the level of teachers' agreement or disagreement on a agree-disagree scale for a series of statements related to: teachers perception of modern parenting techniques as a teacher; parenting approaches teachers are familiar with in school; children's behaviour and attitudes towards school life and teachers' perception about the consequences.

Open-ended question was included into the questionnaire for better understanding of the analysed subject. Teachers were asked to answer a free-form question basing on their complete knowledge, feeling, and perception of the subject at hand. Getting teachers feedback in their own word allowed to probe deeper into the respondent's answers, gaining valuable information about the way how overparenting manifest itself, the difficulties teachers' encounter due to this non-normative parenting behaviour, the ways they cope with it as well as insights into the support that teachers lack to get over the consequences of overparenting more successfully.

Quantitative data was processed using SPSS 11 statistics software package. Qualitative question answers were analysed according to the thematic analysis. The data were analysed and the obtained findings were structured according to the main theme - the experiences of teachers facing overparenting parents and children. The aim was to answer two questions: What difficulties do teachers face when communicating with overparenting parents? What examples illustrate the problems that teachers have identified? The thematic analysis was performed at the following stages: transcription, reading and familiarisation, coding, searching for sub-themes, reviewing themes, defining and naming sub-themes [11].

Sociodemographic characteristics of the survey participants. 262 teachers from 6 countries - Slovenia, Portugal, Romania, Turkey and Lithuania- participated in the survey. $30,2 \%$ of the survey attendees are from kindergarten, $28,3 \%$ - from primary school, $29,5 \%$ - from basic school, $9,7 \%$ - from high school and 1,6\% from other types of school. Vast majority of the research participants are females $(84,9 \%)$. Most of the teachers are very experienced - $66,5 \%$ of them have teaching experience of more than 15 years, $24,8 \%$ - between 5-15 years, less experienced teachers are minority - 9,7\%. Almost half of the participants (45\%) indicates that they work with 21-30 students, $33,3 \%$ of the respondents have 10-20 students in the classroom and $8,9 \%$ of teachers work with less than 10 students.

\section{Research results}

Summarized results of quantitative data. The teachers give positive answers to the question "Have you seen many instances of overparenting?". $22,1 \%$ of the survey participants answer as very often and 40,3\% - often, whereas $34,5 \%$ - sometimes. These replies show that majority of teachers experience overpa-

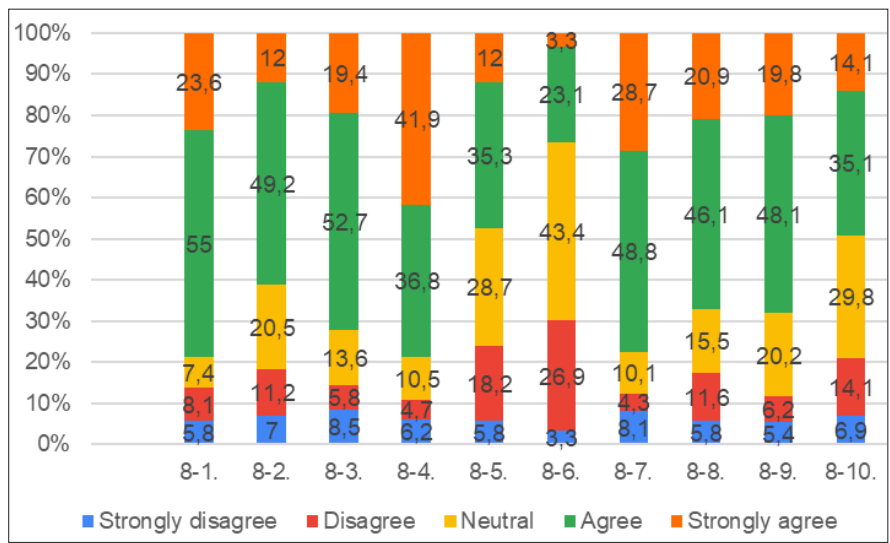

\begin{tabular}{|c|c|}
\hline $\begin{array}{l}\text { Ques- } \\
\text { tion no. }\end{array}$ & Statement \\
\hline $8-1$ & $\begin{array}{l}\text { Within my classroom / school, I perceive different types of paren- } \\
\text { ting techniques }\end{array}$ \\
\hline $8-2$ & $\begin{array}{l}\text { One of the most common parenting techniques used nowadays is } \\
\text { overparenting }\end{array}$ \\
\hline $8-3$ & $\begin{array}{l}\text { Overparenting refers to a parent's attempts to micromanage their } \\
\text { child's life, through well-intentioned actions }\end{array}$ \\
\hline 8-4. & Children who are more autonomous achieve better academic results \\
\hline $8-5$. & $\begin{array}{l}\text { Parents who are more educated and/or economically advantaged are } \\
\text { more likely to over parent their children }\end{array}$ \\
\hline $8-6$. & Parents trust completely in the school system and in the teachers \\
\hline $8-7$. & $\begin{array}{l}\text { There are high expectations towards teachers and the quality of their } \\
\text { teaching methods from the parents }\end{array}$ \\
\hline $8-8$. & $\begin{array}{l}\text { Parents put the responsibility of good academic results on the te- } \\
\text { achers }\end{array}$ \\
\hline 8-9. & $\begin{array}{l}\text { Parents believe that their children's success is a reflection of their } \\
\text { parenting techniques }\end{array}$ \\
\hline $8-10$. & I keep a close relationship with all the parents of my pupils \\
\hline
\end{tabular}

Fig. 1. Teachers' perception on parenting behaviours 
renting attitudes at schools.

Vast majority of teachers $(78,6 \%)$ easily recognize different parenting types at their school and/or classroom (Figure 1). As much as $13,9 \%$ of the respondents do not notice the different parenting types. $61,2 \%$ of the teachers strongly agree or agree that one of the most common parenting techniques used nowadays is overparenting. $18,2 \%$ of the survey participants do not agree with this statement and 20,5\% are neutral. This shows that more than half of the teachers consider overparenting as prevailing parenting behavior. $72,1 \%$ of teachers have a firm perception of what overparenting refers to. They agree that overparenting refers to parents' attempts to micromanage their child's life, through well-intentioned actions. $14,3 \%$ of the respondents would define overparenting in a different way, whereas $13,6 \%$ of the teachers do not have strong and clear position towards overparenting definition. These findings show that among the teaching staff there is still a confusion about overparenting conception.

Overparenting block autonomy of children [2]. This can be regarded as one of the important obstacles on students' success. $78,7 \%$ of the teachers agree that more autonomous children have

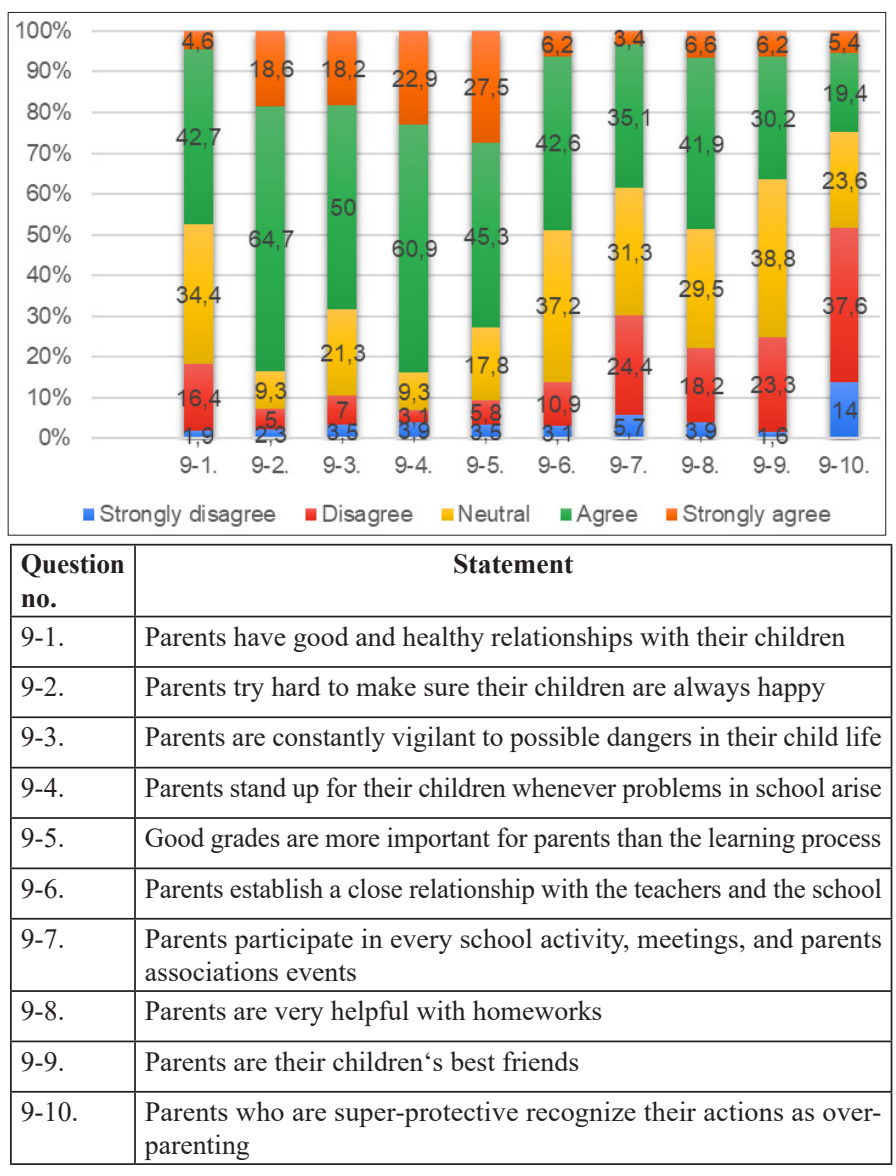

Fig. 2. Parenting approaches observed by teachers better academic results. 10,9\% of the survey participants do not support this statement (Fig.1).

Almost half of the teachers stay neutral $(43,4 \%)$ to the statement that parents trust completely in the school system and the teachers. The positive answers towards the mentioned statement are expressed by 26,4 $\%$, and negative answers by $30,2 \%$ of the survey participants. This shows that there is no a common idea about parents' trust to the system and the teachers. However, majority of teachers $(67 \%)$ think that parents put the responsibility of good education on teachers. The opposite answers are expressed only by $17,4 \%$ of the respondents (Fig. 1). We can say that although teachers stay neutral about trust, they are regarded as responsible for success or failure at school by parents. Results also show that there is a high expectation towards teachers and their quality of teaching (77,5\% of the teachers confirm this). Another interesting result shows that parents think that the success of children is because of better parenting techniques (this idea is confirmed by $67,9 \%$ of teachers). It can be said that parents think that the success of their children is a consequence of their parenting techniques while failure is caused by teachers.

One of the key indicators of overparenting can be seen in the following statement: "Parents try hard to make sure their children are always happy". $83.3 \%$ of teachers agree or strongly agree on it, whereas 7.3 $\%$ of them state negative opinion (Fig. 2). This shows that parents want their children to always be happy and not to experience other feelings. This is a problematic behaviour and sign of over solicitous parenting. 78,2 $\%$ of teachers give positive answers that parents are vigilant to possible dangers in their child's life. This statement is another clear proof of an overparenting attitude. The third very clear proof of overparenting is this statement: "Parents stand up for their children when problems in school arise". $83,8 \%$ of teachers agree or strongly agree on it. This can be recognised as intrusive parenting behaviour. Good grades of children are much more important for intrusive parents and teachers $(82,8$ $\%$ ) agree that their students' parents mainly focus on success rather than other elements of the learning process.

While assessing parents' close relationship with teachers and schools, teachers have different feelings, $48,8 \%$ of the respondents give positive replies, whereas $37,2 \%$ of them stay neutral (Fig. 2). Still almost half of the teachers think that parents are very close with teachers and the school. Teachers don't have a dominant view on the statement about parents' participation in every school activity, meetings and parent 
association events. 38,5\% of the respondents support this statement, whereas $30,1 \%$ of teachers disagree and $37,2 \%$ of them are neutral (Fig. 2). It can be said that when there is a problem specifically related with their children, parents are more sensitive but when there is a common meeting or usual activities, parents might be less sensitive. Also one can assume that parents work during the school time so that they may not join every meeting or activity.

Some statements in the survey stress the autonomy of children and their parents' attitudes. $48,5 \%$ of teachers say that parents help their children with the homework (Fig. 2). 22,9\% of the respondents disagree that homework is perceived as students' responsibility (Fig. 3), 52,4\% of teachers say that children are stressed by school grades (Fig. 3). This shows that students are stressed because their parents always expect success. The problem-solving skills of children seem low according to the survey findings. More than half of the teachers $(56,2 \%)$ think that children establish good and healthy relationships with their peers while $29,5 \%$ of the respondents stay neutral (Fig. 3). This might be a different assumption about the children who face overparenting attitudes and have lower relationships with their peers. About the problems among peers and friends, teachers have different ideas but 46,5\% of them disagree that children are able to deal with friendship difficulties (Fig. 3). 72,1\% of teachers agree that children feel distressed when they aren't able to achieve some goals (Fig. 3). The high parents' expectations and desire of success cause stress on children. This shows the problematic behaviour of children because overparenting.

\section{Summarized results of qualitative data}

The examples in table 1 are illustrations of teachers 'experiences of working with overparented children and interacting with their parents or observing situations that arise during the pedagogical process. The following sub-themes emerged from the analysis of the qualitative data gained from the replies to the question What difficulties do you face when communicating with overparenting parents?: distrust, overprotectiveness, fear of child's failure, low independence, no responsibilities, micromanaging the child (Table 1).

When answering the question What difficulties do you face when communicating with overparenting parents? the teachers point out that communication with parents is difficult. Also teachers do not know how to teach such children, because parents always have too big expectations to the teachers, want to avoid responsibility. Teachers emphasize that parents do not always listen to the teacher, always have their own opinion about their child and what it should be and they refuse another point of view, reject teacher's opinion and they have preconseptions.

Teachers also note that when the initial approach is made to parents about their children's difficulties, parents often do not accept this justifying because they are still very small. In addition, teachers claim that "sometimes parents also argue that there is a lack of understanding on the part of the pedagogical team". Teachers express concern that the results of homework of overparenting children are much better than for tasks done in class. Respondants note that parents pay too much attention to the child, want to do everything to keep the child happy and they don't want to force their kid, even when it is just basic knowledge. Survey participants point out that overparenting parents often are arrogant, do not understand that they exaggerate, do not want to hear arguments and often demonstrate dissatisfaction on evaluation of their child's knowledge. The survey reveals the opinion of teachers that over-caring parents do not accept the teacher's point of view or advice, they are lack of openness to hear suggestions and make changes and lack of empathy with the teacher. Parents tend to hold back independent behaviour of the student. Teachers express

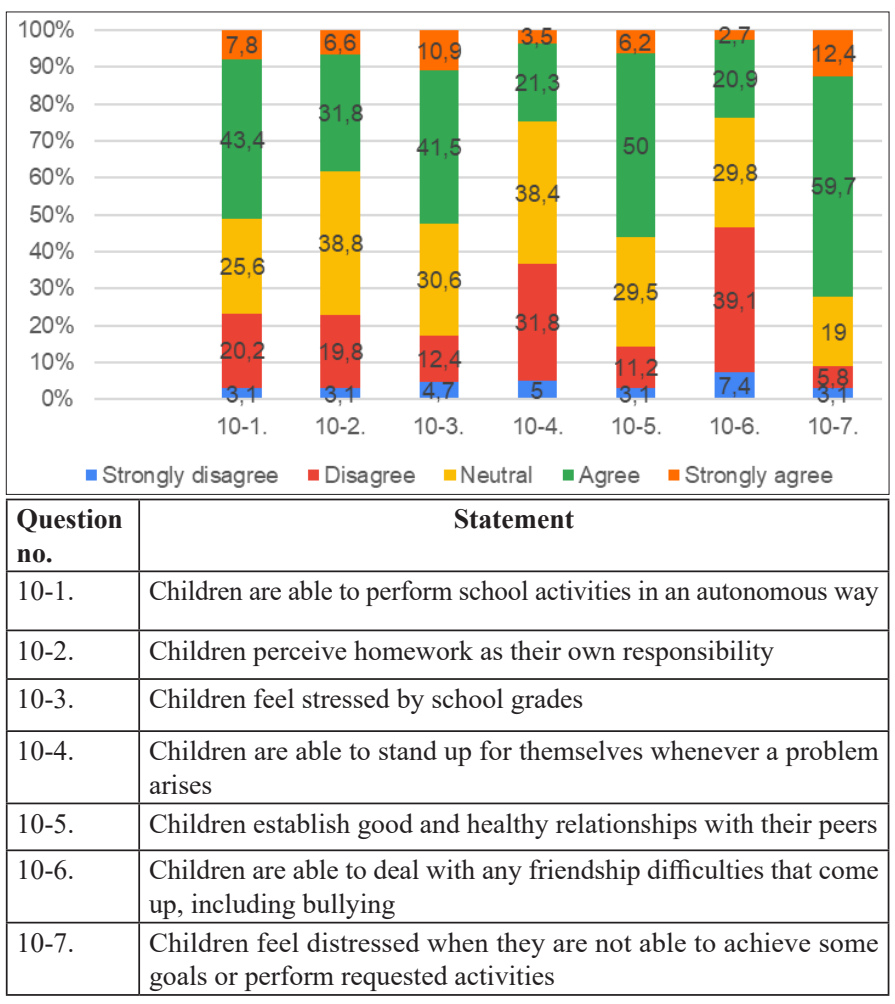

Fig. 3. Teachers' perception about children behaviour and attitudes towards school life 
fear that some parents demonstrate too much attention for the teacher. There are situations when their children feel uneasy due to that, they feel stressed, not self-confident among peers or distrust teacher, make decisions for the child without leaving any possibility for the child to decide. According to teachers, parents think that their children are not able to defend themselves.

The results of survey reveal that teachers face inflexible and contentious parents. Such parental behavior manifests itself as denial, resentment, ignorance, leaving in the middle of a conversation, non-recognition, non-cooperation, resentment. Moreover, parents often raise their voice, speak more rudely, look for excuses that their child did not do that: $p a-$ rents don't hear "like" that their child is causing "problems" at school and then even their response is not as it should be...they are more disappointed in us (teachers) than in the child; all responsibility is placed on others: teachers, canteen workers, cleaners but never see problems in the child's behaviour; too high requirements for teachers, friends, too much focus on problems. Teachers point out parents' inabi-

Table 1. Difficulties faced by teachers when dealing with parents and overparented children

\begin{tabular}{|c|c|}
\hline Sub-theme & Some concrete examples of the teachers' experience \\
\hline Distrust & $\begin{array}{l}\text { Parents send messages through operational assistants to the detriment of their students, fearing } \\
\text { that they will forget to hand them over to their teacher. } \\
\text { In keeping children constantly under control. } \\
\text { Parents prepare their children's backpack. } \\
\text { They walk their child till the clasroom door. }\end{array}$ \\
\hline Overprotectiveness & $\begin{array}{l}\text { Allow not to attend school. } \\
\text { Parents inferfere in the school affairs even when children are over 15. Parents try to protect their } \\
\text { children from every kind of ,, harm” (peer wrestling, finding their place in their own society, ...). } \\
\text { The child does not want to have lunch at school and the parents asked their grandparents to come } \\
\text { and pick him up. } \\
\text { During discussions they say that children are too small and not able to button, tie up, put on shoes etc. } \\
\text { Mother brings a backpack, takes off the books, undresses the child and puts clothes. If she could } \\
\text { she would stay at the lesson instead of the child. } \\
\text { Overfeding his child. }\end{array}$ \\
\hline Fear of child's failure & $\begin{array}{l}\text { Mother calls if the child failed at school }<\ldots>\text { Mother discussed every evaluation (her child is } \\
\text { so smart). } \\
\text { Primary school parents claim tasks are too difficult, children get tired, due to that parents do tasks } \\
\text { for children. } \\
\text { Parents come to the class and prepare books for the lesson. I had one mother who used to come to } \\
\text { her daughter almost every break, brought a roll or a drink. }\end{array}$ \\
\hline $\begin{array}{l}\text { Low independence of } \\
\text { student }\end{array}$ & $\begin{array}{l}\text { Lack of skills to get dressed, to go to the toilet etc. } \\
\text { Children strugle with doing something on their own, he (child)does not have any independence, } \\
\text { parents speak for the child, collect supplies etc. } \\
\text { Do not let the child do things himself what he is already able to do. } \\
\text { Mothers or grandmothers dress and undress pre-school children. } \\
\text { Skills of being independent are not fostered. Parents try to solve children's problems for them without } \\
\text { leaving the possibility to solve themselves. } \\
\text { Parents make excuses when the child does not perform his duties. } \\
\text { Everything is done for the child. }\end{array}$ \\
\hline Micromanaging the child & $\begin{array}{l}\text { Parents too much control the learning process and do not let the child to undertake responsibility } \\
\text { himself, control child's relations with friends. } \\
\text { Do not allow to make decisions, make friends. } \\
\text { Too much care of environment, food. } \\
\text { Father carries } 5 \text { year old child on his arms. Food is mashed for children over } \\
3 \text { to eat without chewing. }\end{array}$ \\
\hline Denial of bad behaviour & $\begin{array}{l}\text { Tolerate bad behaviour and claim other children for that. } \\
\text { The student does not participate in the lesson, ignores me and my words. } \\
\text { Parents not willing to listen on recomodations. } \\
\text { Parents use the words: „My child does not make mistakes” } \\
\text { Constant justification for bad behavior. }\end{array}$ \\
\hline
\end{tabular}


lity to believe that their child may behave badly - the fault is always with colleagues. The survey highlight teachers' concern for parents' lack of understanding that their child is not alone in the class. Sometimes it becomes difficult to explain the situation, if there is a conflict among children, parents can not stay objective. They often do not hear and do not want to hear the problem. Do not try to react to teacher's comments, tend to blame. According to teachers, too little parental responsibility is often identified in the educational process. Parents know their and their children's rights but forget responsibilities.

\section{Conclusions}

The results of the international survey show that parents tend to overprotect their children. More than half of the teachers who participated in the survey notice signs of overparenting in parents as well as in children's behaviour.

One of the main signs of overparenting is the parents' excessive concern for children and the attempt to protect them from all possible dangers. Overparenting parents strive to be perfect parents, they are guided by the false belief that it is their duty to protect their children from all frustrations and environmental dangers. Teachers stress that such caring behaviour does not allow the child to develop confidence in their ability to solve problems and overcome difficulties.

Teachers face excessive parental expectations, ignorance, distrust, anger, indifference to the teacher's remarks and advice, and inadequate assessment of the child's misbehaviour and learning achievements. Teachers find that overparenting promotes children's distrust of their own abilities, unwillingness to accept challenges, and avoidance of more difficult situations in learning.

\section{References}

1. Darling N, Steinberg L. Parenting style as context: An integrative model. Psychological Bulletin 1993;113(3):487.

https://doi.org/10.1037/0033-2909.113.3.487

2. Garst BA, Gagnon RJ. Exploring overparenting within the context of youth development programs. Journal of Youth Development 2015;10(1):5-18. https://doi.org/10.5195/JYD.2015.416

3. Kim K, Rohner RP. Parental warmth, control, and involvement in schooling: Predicting academic achievement among Korean American adolescents. Journal of Cross-Cultural Psychology. 2002;33(2):127-40.

https://doi.org/10.1177/0022022102033002001

4. Baumrind D. Effects of authoritative parental control on child behavior. Child Development 1966:887-907.

https://doi.org/10.2307/1126611

5. McCoby EE. Socialization in the context of the family: Parent- child interaction. Handbook of Child Psychology 1983;4:1-01. 6. Segrin C, Woszidlo A, Givertz M, Bauer A, Taylor Murphy M. The association between overparenting, parent-child communication, and entitlement and adaptive traits in adult children. Family Relations 2012;61(2):237-52. https://doi.org/10.1111/j.1741-3729.2011.00689.x

7. Thomasgard M. Parental perceptions of child vulnerability, overprotection, and parental psychological characteristics. Child Psychiatry and Human Development 1998;28(4):223-40. https://doi.org/10.1023/A:1022631914576

8. Locke JY, Campbell MA, Kavanagh D. Can a parent do too much for their child? An examination by parenting professionals of the concept of overparenting. Journal of Psychologists and Counsellors in Schools 2012;22(2):249-65.

https://doi.org/10.1017/jgc.2012.29

9. Segrin C, Woszidlo A, Givertz M, Montgomery N. Parent and child traits associated with overparenting. Journal of Social and Clinical Psychology 2013;32(6):569-95.

https://doi.org/10.1521/jscp.2013.32.6.569

10. Padilla-Walker LM, Nelson LJ. Black hawk down?: Establishing helicopter parenting as a distinct construct from other forms of parental control during emerging adulthood. Journal of Adolescence. 2012;35(5):1177-90.

https://doi.org/10.1016/j.adolescence.2012.03.007

11. Braun V, Clarke V. Using thematic analysis in psychology. Qualitative Research in Psychology 2006;3(2):77-101.

https://doi.org/10.1191/1478088706qp063oa

12. Amato PR, Dorius C. Fathers, children, and divorce. 2010.

13. Cullaty B. The role of parental involvement in the autonomy development of traditional-age college students. Journal of College Student Development 2011;52(4):425-39.

https://doi.org/10.1353/csd.2011.0048

14. Darling N. Parenting Style and Its Correlates. ERIC Digest 1999.

15. Bayer JK, Sanson AV, Hemphill SA. Parent influences on early childhood internalizing difficulties. Journal of Applied Developmental Psychology 2006; 27(6):542-59.

https://doi.org/10.1016/j.appdev.2006.08.002

16. Gar NS, Hudson JL. An examination of the interactions between mothers and children with anxiety disorders. Behaviour Research and Therapy 2008;46(12):1266-74.

https://doi.org/10.1016/j.brat.2008.08.006

17. Montgomery N. The negative impact of helicopter parenting on personality. InPoster session presented at the annual meeting of the Association of Psychological Science, Boston, MA 2010.

18. Rapee RM. Early adolescents' perceptions of their mother's anxious parenting as a predictor of anxiety symptoms 12 months later. Journal of Abnormal Child Psychology2009;37(8):1103-12.

https://doi.org/10.1007/s10802-009-9340-2

19. LeMoyne T, Buchanan T. Does "hovering" matter? Helicopter 
parenting and its effect on well-being. Sociological Spectrum 2011;31(4):399-418.

https://doi.org/10.1080/02732173.2011.574038

20. Givertz M, Segrin C. Effects of overinvolved parenting on young adults' identity and family satisfaction. Communication Research 2013, 32 (6), 569-595.

\section{MOKYTOJŲ PATIRTYS, DIRBANT SU HIPERGLOBOJANČIŲ TĖVŲ VAIKAIS}

L. Navickienė, I. Kupčikienė, E. Stasiūnaitienė, M. Tokgöz, E. Koçak

Raktažodžiai: auklejjimo metodas, hipergloba, mokytojų patirtys.

\section{Santrauka}

Dauguma tèvų sutiktų, kad auklëjimas yra labai sudètingas ir iššūkius keliantis procesas. Tai nuo pat kūdikystès prasidedantis ir visa gyvenimą trunkantis fizinio, emocinio, socialinio ir intelektinio vaiko vystymosi ir palaikymo procesas. Vaikai negimsta sèkmingi ar nesėkmingi. Tèvai ir jų elgsena turi lemiamos įtakos tam, kuo vaikai tampa. Sveika, pozityvi tèvystė yra būtina vaiko sèkmès, pasitikejjimo savimi ir savarankiškumo sąlyga. Tuo tarpu perdèta globa, nesveika tèvystė gali pakenkti vaiko socialiniams igūdžiams ir bendrai gyvenimo sèkmei.
Tyrimu siekta išsiaiškinti mokytojų patirtis apie tèvų taikomus auklejjimo ypatumus ir atskleisti šiandieninejje vaikų auginimo praktikoje vyraujančius auklejjimo metodus. Tyrimo tikslui pasiekti parengta tyrimo priemonè, kurios konstruktas grindžiamas hipergloba pasižyminčios tèvystès požymiais. Atliktas tarptautinis tyrimas leido identifikuoti pagrindinius mokytojų, dirbančių su hiperglobojančiais tèvais ir jų vaikais, patirties aspektus. Tyrime dalyvavo 262 mokytojai iš Portugalijos, Slovėnijos, Turkijos, Rumunijos ir Lietuvos.

Tyrimas atskleidè vyraujančias tèvų taikomas hiperglobos elgsenas. Tyrimo rezultatai leido išskirti pagrindinius sunkumus, su kuriais susiduria mokytojai, bendraudami su hiperglobojančiais tèvais ir jų vaikais.

Tyrimas atliktas ịgyvendinant tarptautinị projektą „Overparenting - allow your children to make mistakes“, Nr. 2020-1-PT01KA204-078497.

Correspondence: lijana.navickiene@go.kauko.lt

Gauta 2021-10-19 